\title{
Analysis of the Determinants of Public Education Expenditures in Bangladesh
}

\author{
Md. Rashidul Islam Sheikh \\ Associate Professor, \\ Department of Public Administration, Comilla University, Bangladesh and $\mathrm{PhD}$ \\ Candidate at \\ Graduate School of Public Administration (GSPA), National Institute of Development \\ Administration (NIDA), Bangkok, Thailand-10240 \\ E-mail: mrisheikh@yahoo.com
}

Received: Aug. 7, 2019 Accepted: Sep. 2, 2019 Online published: Sep. 10, 2019

doi:10.5296/jpag.v9i3.15419 URL: https://doi.org/10.5296/jpag.v9i3.15419

\begin{abstract}
This study based on the well-known theories of public policy analysis, economics, as well as public finance through empirically exploring and examining the determinants of public expenditure on education in Bangladesh. It is postulated, for the purpose of the research that education expenditures are determined by multidimensional factors. Economic-demographic, decision-making, political, and new institutionalism theories are therefore been studied, along with the concept of education. This research identified as well as computed education expenditure by types along with levels of education as per the distribution of government budget and the education system of Bangladesh. The results disclosed that education financing policy in Bangladesh is primarily determined by the previous year's expenditures. Indirect tax also increased the total education expenditure as percentage of GDP. This is what in line of incrementalism theory and fiscal illusion or voting bias model suggests, respectively. Furthermore, total populations and government effectiveness has the positive impact of types as well as levels of education expenditures; implying that government of Bangladesh taken under consideration only certain factors and neglects to incorporate the importance of economic, governance and educational determinants while allocating education expenditures.
\end{abstract}

Keywords: education expenditure, public policy analysis, fiscal policy, Bangladesh

\section{Introduction}

Within the past few decades have been perceived numerous challenges for fiscal economizing as well as reform of fiscal policy. Government's incapability to use expenditures efficiently 
and effectively to endorse the people's needs determines the necessity for fiscal reform, at least in certain areas. Improved wisdom as well as in-depth understanding of a certain public expenditure issue might be a significant component of the tactic for reaching desirable policy outcomes.

In Bangladesh, five-year plans from very beginning of the independence in 1971 and recent past MDG have placed massive weight on human capital development. Consequently, the education expenditure has the principal share in the aggregate budgetary allocation. Furthermore, there has also been an upsurge of this types of expenditure since last few decades, regardless of which political party in power or even in the regime of coup d'état. The noteworthy expansion of education expenditure in Bangladesh due to the development strategy of the Bangladesh justifies a systematic analysis of the determinants working behind the scene.

A good number of research, has already included the theoretical backdrop in economics which analyzes the education policy apparatuses through the international or international comparison point of view, especially the determinants of educational expenditure (Fernandez \& Rogerson, 1997; Hanushek, Eric A, Rivkin, 1997; Ram, 1995). Some of the research analyze public expenditure from decision making point of view (Saeki, 2005; Tandberg, 2009, 2010). Even though, cross-country analysis is theoretically appreciated, preceding studies have found them uninformative in pointing out the determinants of policy limitations, which vary according to the socio-economic, historical as well as political backgrounds of each country.

This paper contributes in the literature by examining quite a few dimensions like economic-demographic, decision making, political, governance along with practical bases of the determinants and impact of educational expenditure in Bangladesh. It uses the most recent and extensive data which specifically investigates the vital determinants of public educational expenditure in Bangladesh by viewing at different levels of education and types of expenditure. The results of this paper can help explaining some existing vagueness about how exactly the government behaves while making education policy.

\section{Theoretical Framework}

In studying the public education expenditures, a substantial numbers of public expenditure theories or public policy theories are essential indeed to provide the foundation of understanding the different types of variables that may determine the public education expenditure in the socio-political context of Bangladesh. The selected theories under this paper reflected the socioeconomic-demographic, decision making, governance indicators as well as political policy determinants. A Multi-Faced Examination of Policy Determinants Framework for Analysis of educational expenditures (MPDFA) is formulated for covering the theories under this paper.

\subsection{Keynesian Counter-Cyclical Theory}

Keynesian counter-cyclical theory arguers that the choice of allocating more or less public expenditure depends on the condition of the particular society, implying that any changes in 
economy that dictate the government to reshuffle the public expenditure allocation. In the 1930s, Keynes General Theory and during the Keynesian insurgency, roughly the world government began to observation economic stabilization as their main duty (Mankiw, 2010). General Theory of Keynes being fashionable by the leading study through Alvin Hansen, Abba Lerner, Lawrence Klein, and many more; and provides apparatus for economic stabilization, indeed and still another commanding reason for government intervention (Tanzi $\&$ Schuknecht, 2000, p. 10). It is the norms of public policy taking steps responding to any changes or fluctuations of economy, for example, the economic growth or unemployment level; meaning that the stages of public expenditure are determined according to the conditions of the economy.

Now the prime query in this study is, whether the expenditure of education acts oppose or in support of at regular intervals. Normally, other kinds of societal expenses is fluctuated accordingly with the movement of economic scenario or environment (Busemeyer, 2007). In education, though, correlation between economic environment and public expenditure seems to be more indirect but financial depression do not in a straight-line direction to the closure of educational institutions or teacher forcedly remains out of services. Furthermore, if the effect of financial determinants towards the expenditure of education remain roundabout and perpetuated in characteristics, then the analyzes of cross-sectional differentiation rises in significance in the context of time-series investigation (Busemeyer, 2007). For example, in some cases, financial depression could lead to the closure of schools that happened in the U.S.A during economic crisis.

\subsection{Economic-Demographic Theory and Wagner's Law}

This theory pinpointed on the substances of socioeconomic as well as political factors that is generally determining public expenditures. Wagner's theory is founded on traditional democratic system theory where it is assumed that political system no way but to pay head to the demand arising from the environment (Easton, 1965, p. 22). Public expenditure/policy which is treated as an outcome of political systems model is highly anticipated to be accountable to the socioeconomic as well as political demand arising from the environment.

In accordance to the opinion of Thomas R. Dye, the notion of "system" meaning a composition of formal organizations and actions in humanity that functioning to change wants into trustworthy levels that need endorsement from the entire humanity. The model of "system" or model further indicating that the system is to act in response to the demands arising from its surroundings (Dye, 1978, p. 38). Wagner explained his replica of public expenditure escalation in an effort to simplify as well as illustrate the modifications in the level of public expenditure. He further illustrates three key causes for increasing government attachment for example, industrialization, modernization, and growth in real income (Wagner, 1958).

\subsection{Compensation Theory}

Compensation theory argues that, globalization has an influence on public spending. This theory has originally been developed by some international trade scholars i.e. (Garrett, 2000; 
Garrett \& Mitchell, 2001; Rodrik, 1998; Ubiergo, 2007) shows that globalization has extended administrative interference in the financial system and accordingly pushed the administration to raise social program related expenditure (e.g. education program). Here in this connection, the governments do best for compensating those who lost their works resulting from trade liberalization as well as this forces push the government to increase budgetary allocation (Balcells Ventura, 2006; Rodrik, 1998; Yoon, 2009). But major question is, whether the government can compensate those who have lost their livings?

In addition, the legislators are often faced a different dimensions of political constraints that may lead the policy makers, not to find out the real societal goals as well as the assessment of expenses and benefits (Dye, 2005, p. 18). This is may be the hidden cause to appoint experts some times to take assistance from them by the government about future policy making trend (Etzioni, 1967, p. 386; Lindblom, 1959, p. 84).

\subsection{Decision- Making Theory}

Incrementalism model is naturally decision making process in the pluralist societies which is claimed by Lindblom (Lindblom, 1959). This model is very popular to politicians and or decision makers because it is easier to make consensus on dispute and no major or magnitude changes in policy or program of status quo. According to this view of incrementalism model, policy formulation or making process goes on following several types of political chain relationships and stages, having no quick begging or ending and there is no clear boundaries, and policies are to be altered incrementally over time to the existing one (Quade, 1982, p. 27). Still the inspection of the policy procedure articulated by Lindblom (1959) is additionally practical compare to that of which seems to be implicit in much research (Quade, 1982). In fact, public expenditure of education as characterized as incremental and policy makers take the last year's budget as a baseline and modify or adjusting with the current expenditure from that of last year allocation.

\subsection{Public Choice Theory}

Political factors are the critical role player under the purview of this theory. It is based on the neoclassical economic theory and postulates that everybody like politician, civil servants, voters, all are working for their self-interest, and for the greater interest of profit maximizesthat is critical nature of human in the developing country (Sagarik, 2013). In a nutshell, this is the self-driven mutual interaction between decisive voters and politicians which often shape the public policy as well as public expenditures.

\subsubsection{Median Voter Model}

This model argues that, the volume of government differ by the percentage of mean income in terms of the income of the key supporter as well as with the voting law or credentials for voting (Meltzer, Allan H and Richard, 1983). A little bit earlier, the same logic had been established by (Peltzman, 1980) arguing that the total increase may be endorsed to the combination of vote-maximizing politicians as well as voter demand driven income redistribution. Henrekson pointed out that, this can be experienced by counting the proportion of mean pre-tax income as an independent variable (Henrekson, 1988). Tanzi and Schuknecht 
(2000) suggest a possible way out of this difficulty by daunting legal restrictions to public expenditure growth while there is a tendency that governments will overspend to get more acceptances from the voter.

\subsubsection{Voting Bias Model}

An additional important variation to public choice theory is alleged fiscal illusion model developed by a substantial number of scholars, for example (James M Buchanan, 1975; James M Buchanan \& Wagner, 1977; Marshall, 1991; Oates, 1988). This model believes that the government has choices for mounting government's public expenditure for larger budgets are said to be for fulfilling the need to make happy regarding the rising claim of the people (Buracom, 2011). In this scenario, government must increase tax base or tax horizon to adjust the demand arising from the society or the constituency. Conversely, imposing higher taxes must dissatisfy other segments of voters. Henceforth, government tries to collect more taxes which are less noticeable or are hard to realize by the general people. Therefore, to make happy the voters, often government tries to mask tax burdens basically in indirect taxes and thereby run into fiscal deficits.

\subsubsection{Budget-Maximizing Bureaucrats Model}

This model believes that bureaucrats intended to have bigger budgets (Borcherding, 1977; Ferris \& West, 1999; Niskanen Jr, 1971) as well as the indispensable monopoly over the public production along with the governing body to pose their own system to grasp their objectives. This larger budget can be used not only to offer higher salaries and more leisure time, but further can build also a higher public status and supremacy for the government department (J M Buchanan \& Tullock, 1977; Buracom, 2011). Romer et.al developed a model "Political Resource Allocation" in which civil servants can compel constituents to prefer a bigger amount of public expenditure compared to that of most favored by the median constituent (Romer \& Rosenthal, 1978). Mueller (1987) argued that there is expected to be constructive association connecting the total volume of the civil service as well as the speed at extent of the government grows. Mueller further concluded that, "the bigger the bureaucracy is, the more difficult it is for outsiders to monitor its activity, and the more insiders there are who are working to increase the size of the bureaucracy" (Mueller, 1987, p. 138).

\subsubsection{Political Business Cycle Model}

Macroeconomic policies are frequently modified or are influenced by electoral incentives of political parties or the party in power. Consequently, fiscal policy is influenced by the electoral motivations of politicians. A number of scholars, for example (Alesina \& Roubini, 1992; Hibbs, 1994) argued that business cycle is created by the competition for elections among political parties and or the government can itself create this political cycle. As per the argument of this model, the government as well as the political parties is unsaid to be self-absorbed and accordingly their key concern is to be successful in a voting. 


\subsection{New Institutionalism Theory}

This theory believes that economic growth is not dependent only on the investment in physical as well as human development but also dependent on the active support of some legal as well as government institutions, including an effective legal institution that can enforce the contracts and property rights which enable the business man making an ease business contract due to be enforceable with trust. On the other, a system of good governance that particularly incorporates the government and civil service system that are transparent as well as accountable which enhances the trust as well as cooperation among citizen, businessman and the government; and the democratic political system which can protect political freedom along with political rights. Henceforth, the performance of the government in policy formulation as well as policy implementation capacity increases and under this study this performance may lead to the effective performance in dealing with educational expenditure of Bangladesh.

Government must respond to any change of the economic environment and education is growing demand from all strata. In that case, Keynesian Countercyclical theory provides strong tools for economic stabilization and government use these as means for intervention.

Economic-demographic theory and Wagner's law explains public expenditure in many cases and increase more than revenue collected and politicians are faced pressure, and are not easy to control as well as fulfill the growing demand of population growth, basic services, number of schools etc. As population increase, hence they will join different levels of education and accelerated the education expenditure. In that case government is bound to extend different social welfare related activities which finally produced spillover effect on economic development.

As policy makers are constrained by time, information regarding citizens' need, and are not responsive to the environment; henceforth they allot expenditure based on last years' budget which is incremental by nature.

Political factors are the critical role player explained by public choice theory and postulate that politician, civil servants, voters, all are working for their self-interest, and for the greater interest of profit maximizes- that is critical nature of human in the developing country. In a nutshell, this is the self-driven mutual interaction between decisive voters and politicians which often shape the public policy, in this case public expenditures on education.

Active support of legal institutions and transparent government is essential in economic growth, as economic growth incorporates the human development; henceforth increasing education expenditure is natural.

\section{Empirical Evidence of the Studies}

There is massive literature on Wagner's Law relating to government expenditure in general. A huge number of studies, like Fernandez \& Rogerson (1997); Hanushek, Eric A, Rivkin (1997); Ram (1995) found and more or less particularly focused on socio-economic variables, for example, GDP, enrollment rate of students, number of teachers, per-capita income, etc. 
indicating the close association with the public expenditure, particularly on education expenditure. Studies of Kolluri, Panik, \& Wahab (2000) studied Wagner's law applying time-series statistics to the G7 states during the time frame of 1960 to 1993, and showed that the regulation holds due to some of the apparatus of government spending for G7 states equally the short term and long term perspectives. In the study of Hanushek, Eric A, Rivkin (1997) showed that changes in enrollment have significantly exaggerated educational spending along with the amplifying of the costing of outside expenditure as well as staff.

Another study examines the demographic change and its impact on public education expenditure allotment in the context of East Germany, for example Kempkes (2010) who pointed out that recourse modification appears to be mainly strong in times of diminishing student cohorts during 1993-2002 in East German context. In the recent past study from Switzerland using panel data, based on demographic change during the period of 1990-2002, for example Grob and Wolter (2007) pointed out that the education system has showed little elasticity in adjusting to changes in the school-age population, and that the share of the aged population has a notably negative influence on the eagerness to pay out on public education.

In the study of Saeki (2005) by the state governments of U.S.A in 2000, shows the orderly determinants, for example, incrementalism; had profound control on education. Another research of Shelley and Wright (2009) used panel regression to analysis diverse measurements of state's tertiary education spending over 45 states during a time frame of 1986 to 2005 in to the U.S.A and results is reliable along with the incremental theory of public spending as well as implying that time-series of these variables ought to be differentiated if applied as predictor variables in regression models. Additionally, the study of Tandberg (2009 \& 2010) find out the further support to the implication and the guess of incrementalism model. In the study of Radcliff and Saiz (1998) as well as Saeki (2005), found that the amount of educational spending is mostly influenced by the size of the government.

Voting bias model or fiscal illusion is another important variation of public choice model which also play a crucial role in determining public policy, predominantly in educational expenditure in total, fiscal illusion model is examined by means of tax returns configuration as a determinant of escalation rate of public spending (Heyndels \& Smolders, 1994). Budget deficit also can be explained by fiscal illusion model and testing its impact on public expenditure in terms of economic growth rate.

The working paper of Portrafke (2006) analyzes the expenditure trend to the German national level during the time period of 1950 to 2003 and found partisan politics and election year effects as an evidence. Theoretically and practically important issue that the vote or electoral democratic competition drive an indication and has well-built effect on public expenditure, mainly on welfare spending, for example the study of Comiskey (1993) of domestic spending in capitalistic democracies from 1950 to 1973 and 1973 to 1983; where author clearly pinpointed that electoral contest determines the expansion of public expenditure and the party leader or contender foresee the requirement for higher welfare from voters and endeavor to convince constituents by rising welfare spending amount. 
The educational expenditure has also been analyzed via the political business cycle model in economic literature, indeed. The political party's stay in office or the length in office also matters and has a crystal-clear signal towards public expenditure affairs. In a study, for example of (Kemnitz, 1999) examining societies age structure, clearly pointed out that a longer voting cycle would entail a less subsidy fee for public education. This is undoubtedly indicating the connotation of the pressure of politics on public policy making decision, especially regarding the expenditure of welfare.

\section{Methodology}

\subsection{Conceptual Framework}

In Bangladesh, there are three main stages or levels of formal education, which are primary (Class 1-5), Secondary education (6-10) or to some extent it varies across schools (9-12), Higher education levels means Tertiary levels of education. Besides these levels of education, there is non-formal education system is simultaneously operating in Bangladesh. Another stream of education in Bangladesh is called the Islamic religious education- means Madrasah system containing five stages of education program along with the English medium system of education (Ordinary Level- O level and Advance level- A level) is operating under different curriculum, equivalent to main stream education of Secondary and Higher Secondary level of education respectively in Bangladesh. But for this study, primary, Secondary and Higher education is taken as for allocation of public expenditure on education and other educations or levels of education are excluded.

Specifically, education expenditure alike different kinds of public expenditure can be categorized by types. Public expenditure has two main types which widely known in economic literature that are development expenditure and recurrent expenditure. In fact, these two types of expenditure form the total educational expenditure. Development educational expenditure is considered to be very crucial for particular country's advancement as well as the upgrading of governmental services for example, procurement of educational equipment, building additional construction like school, colleges, Universities etc. The recurrent expenditure is not included in this study because of data unavailability, but these can be the tool of the government for getting continues support from the civil bureaucrats. The conceptual framework for this paper will be explained by the figure 1 .

For demonstrating the economic-demographic or systems model in the context of Bangladesh education expenditure, GDP at current prices, inflation rate, population growth, urbanization, globalization and unemployment rate is selected as these variables are closely associated to the education expenditure in Bangladesh. Some of the variables are examined in Kenya by Imana (2017). In addition to these, variables of education indicators also been taken into consideration, since these variables may dictate the demographic prototype in the scenario of education policy means education expenditure as well as are pertinent to the socio-political context of Bangladesh. This includes the enrollment rate, number of schools, and student-teacher ratio which are used by many empirical analyses, including Ram (1995), Hanushek and Rivkin (1997), Fernandez and Rogerson (1997), Kempkes (2010), Grob and Walter (2007) and Sagarik (2013). 


\section{Macrothink}

Journal of Public Administration and Governance

ISSN 2161-7104

2019, Vol. 9, No. 3

Public expenditure also has to do with governance indicators which implies that a system of good governance that particularly incorporates the government and civil service system that are transparent as well as accountable which enhances the trust as well as cooperation among citizen, businessman and the government; and the democratic political system which can protect political freedom along with political rights. Henceforth, the performance of the government in policy formulation as well as policy implementation capacity increases and under this study this performance may lead to the effective performance in dealing with educational expenditure and also is crucial for intervening public expenditure in the context of developing country like Bangladesh.

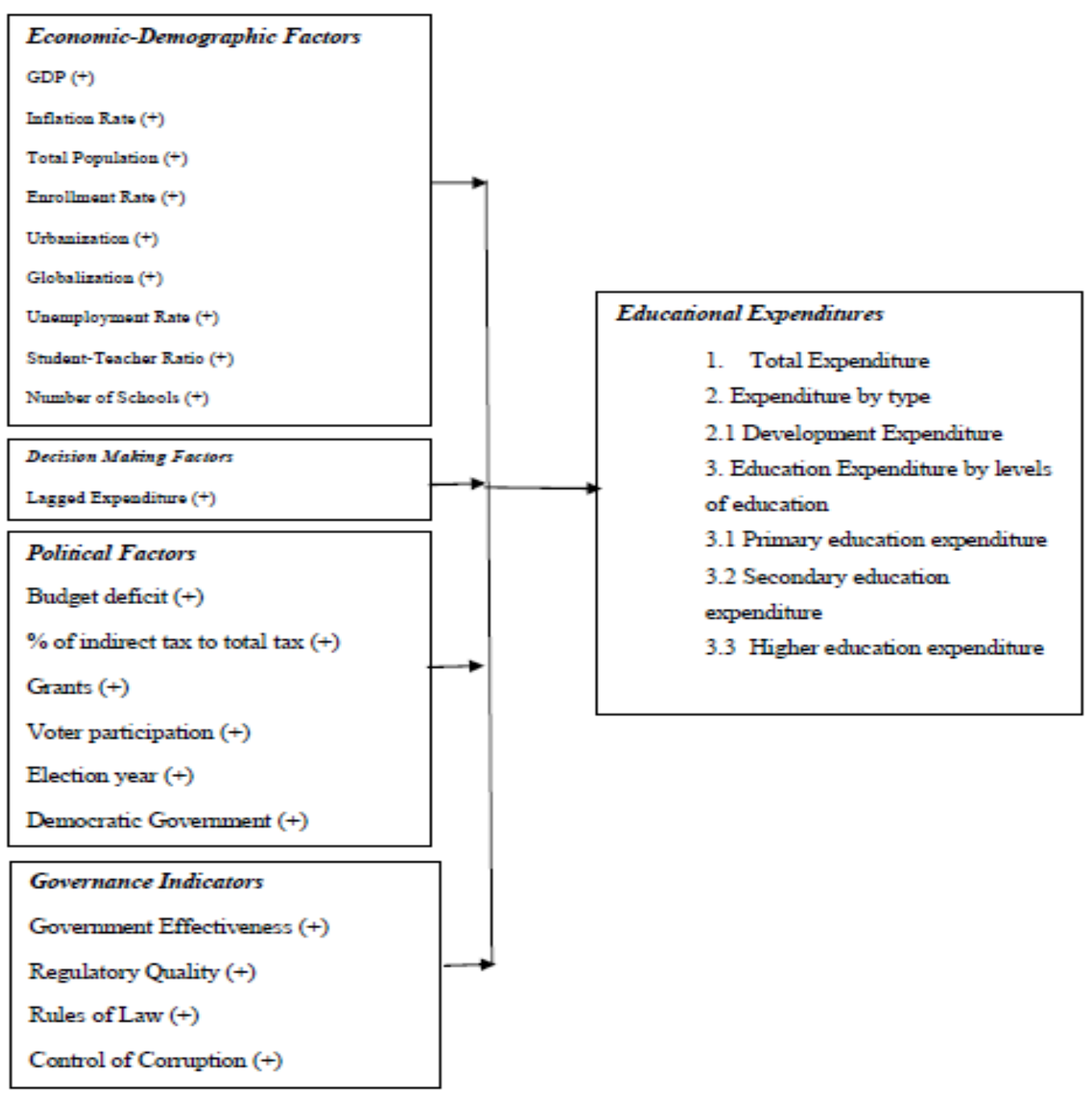

Unit of Analysis is Year of 1980-2018

Figure 1. Conceptual Framework: Multi-Faced Examination of Policy Determinants Framework (MPDFA) Analysis for Education Expenditures

These includes, enrollment rate, teacher employment, number of schools (schools, colleges and universities), student-teacher ratio, number of school age populations, that has already been used in many papers analyzes, for example Fernandez and Rogerson (1997), Grob and Wolter (2007), Kempkes (2010) and Imana (2017). 
Only one variable "lagged expenditure t-1" under decision making factors also called incrementalist factors in total educational expenditure is crucial, therefore already mentioned as independent variable in the conceptual framework; assuming that this variable has encouraging and important coefficient in terms of moving the education expenditure in positive direction, for example, Thailand and Kenya already proved that in the country context study. That's the reason for testing the incremental variable in the context of Bangladesh education expenditure.

Under the political factors, budget deficit is taken under consideration for determining the size of the government which is examined by Radcliff and Saiz (1998) as well as Saeki (2005). The percentage of indirect tax to total tax is considered for illustrating fiscal illusion theory as a proxy variable. The amount of indirect tax is very high in Bangladesh and politicians used this for promoting education expenditure. Grants also used to explain fiscal illusion theory- how foreign donation or grants can affected on public education expenditure. The indirect tax and grants is also examined in Kenyan context by Imana (2017). Democratic government and Voter participation (Peltzman, 1980) is used to test the median voter model of public choice because most of the people in Bangladesh live in the rural areas and most of them are living on agriculture. Political business cycle model is tested by the election year as this variable is used by a good number of papers which is reviewed in theoretical section, for example Kemnitz (1999) as well as Potrafke (2006).

\subsection{Research Method}

The multiple regression technique is applied for the empirical analysis of the quantitative data using time-series of 39 years of annual data. In examining the determinants of education expenditure by type and levels, annual data of government expenditure from the World Bank and Ministry of Finance of Bangladesh from 1980 to 2018 are used, (See table 1, 2, 3, 4 in APPENDIX: A, B, C and D, data for independent and dependent variables). This data is treated as quality sources of quantity data regarding government budget in Bangladesh. The initial model specifications of each type and levels of education expenditure demonstrated as comprising altogether five models extracted from the conceptual framework. Model 1-5 included all the exploratory variables from the MPDFA for every predicted variable to examine the determinants of educational expenditures. The selected exploratory variables echo the policy standpoint given to each type of education from policy viewpoint and are regressed with a set of exploratory variables.

\section{Empirical Results}

It is imperative to mention the descriptive statistics to offer overall idea of the characteristics of education expenditure in Bangladesh before moving on to the discussion of the regression results. Table 5 (APPENDIX: E) depicts the summary of descriptive statistics of both the dependent as well as independent variables. Two independent variables- democratic government and election year are not included in table as they are used as dummy variables.

\subsection{Correlations and Multicollinearity}

This research firmly considered the concern of multicollinearity problem. When two 
independent variables are highly as well as positively correlated, coefficient estimations tend to be very unstable from one sample to the next one. The greater the multicollinearity, the greater the standard errors. This problem can be sensed by examining the bivariate correlations between the predicted variables as well as looking for greater values (e.g., 0.80).

The multicollinearity problem is further of concern when the value of the VIF is greater than 10 and the tolerance value is less than .1. So, some independent variables are removed from the model when there are high levels of bivariate correlations. Consequently, including the same or almost the same variable twice can generate multicollinearity problem. To perceive as well as avoid the multicollinearity, this study contemplated both examining correlations as well as using values of tolerance and VIF.

\subsection{Model Specifications}

After removing the variables that exhibit multicollinearity problem, the five regression models then become;

$T G E=a 1+b 1 L A G \_E X P+b 2 I D T+b 3 I N F+b 4 G L O B+b 5 S C H+b 6 G R A N T S+b 7 D G O V+e$

Model 1

$E C A P=a 2+b 8 I N F+b 9 P O P+b 10 G L O B+b 11 S C H+b 12 D G O V+b 13 G R A N T S+b 14 I D T+b 15$

$E L E C+b 16 G E+e$

Model 2

$G P=a 3+b 17 G L O B+b 18 L A G_{-} E X P+b 19 I N F+b 20 P O P+b 21 S C H+b 22 D G O V+b 23 E L E C+$

b 24 STR $-P+e$

Model 3

$G S=a 4+b 25 I N F+b 26 P O P+b 27 G L O B+b 28 S C H+b 29 D O G V+b 30 I D T+b 31 G R A N T S+b 32$

$L A G \_E X P+\mathrm{e}$

Model 4

$G U=a 5+b 33 I N F+b 34 P O P+b 35 G L O B+b 36 I D T+b 37 S C H+b 38 D G O V+b 39 G R A N T S+b 40$

$E L E C+b 41 L A G \_E X P+e$

Model 5

The above newly developed five regression models are to be used for the Multiple Linear Regression Analysis (MLRA) due to the determination of estimation of the determinants of education expenditures in Bangladesh. Regressing all the sets of predictor variables separately for type as well as levels of education can categorize conceivable counteracting determinants of education expenditures. Development education expenditure will incorporate the same set of predictor variables except lagged expenditure.

\subsection{Results and Discussion}

Tables 2, 3, 4, 5 and 6 depict the estimation of the regressions of types and levels of education expenditure in Bangladesh. The estimated outcomes allow us to perceive whether the variables in the MPDFA framework have significant impacts on education expenditures. Already discussed that some of the independent variables are removed from the model because of having multicollinearity and the coefficient estimation which do not appear in the tables are thus absent having of multicollinearity problem. 
Table 2. Estimations of the Determinants of Education Expenditure: TGE

\begin{tabular}{|c|c|c|c|c|c|c|c|}
\hline \multirow[t]{2}{*}{$\begin{array}{c}\text { Independent } \\
\text { variables }\end{array}$} & \multicolumn{2}{|c|}{$\begin{array}{l}\text { Unstandardized } \\
\text { coefficients }\end{array}$} & \multirow{2}{*}{$\begin{array}{c}\begin{array}{c}\text { Standardized } \\
\text { coefficients }\end{array} \\
\text { Beta }\end{array}$} & \multirow[t]{2}{*}{$\mathrm{T}$} & \multirow[t]{2}{*}{ Sig. } & \multicolumn{2}{|c|}{ Collinearity statistics } \\
\hline & B & $\begin{array}{l}\text { Std. } \\
\text { Error }\end{array}$ & & & & Tolerance & VIF \\
\hline Constant & .333 & .592 & & .563 & .578 & & \\
\hline $\begin{array}{c}\text { Lagged } \\
\text { expenditure }\end{array}$ & $2.693 \mathrm{E}-5$ & .000 & .673 & 2.939 & $.006^{*}$ & 0.169 & 5.914 \\
\hline Indirect tax & .028 & .006 & .605 & 4.497 & $.000^{* *}$ & 0.490 & 2.040 \\
\hline Inflation rate & -.042 & .017 & -.321 & -2.431 & $.021^{*}$ & 0.507 & 1.974 \\
\hline Globalization & -.003 & .001 & -.410 & -2.718 & $.011^{*}$ & 0.389 & 2.568 \\
\hline $\begin{array}{l}\text { Number of } \\
\text { schools }\end{array}$ & $-2.369 \mathrm{E}-6$ & .000 & -.043 & -.234 & .817 & 0.265 & 3.772 \\
\hline Grants & -.024 & .008 & -.372 & -2.983 & $.006^{*}$ & .568 & 1.759 \\
\hline $\begin{array}{l}\text { Democratic } \\
\text { govemment }\end{array}$ & -.243 & .184 & -.250 & -1.322 & .196 & .247 & 4.045 \\
\hline $\mathrm{R}^{2}=0.734$ & Adjusted R & 0.672 & F-statistic $=$ & 1.838 & Dur & -Watson s & $=2.495$ \\
\hline
\end{tabular}

The regressions analysis explains up to 67.20 and 76.40 percent respectively of the variation in the education expenditures between types during the time. Table 2 shows the coefficient of inflation rate (INF) is significant but has negative sign. It is implying that, when price levels increase, the total expenditure of the government on education decrease. It offers support to the Keynesian Counter-Cyclical theory to the extent that inflation has a negative impact on government expenditure, and especially in this case of education expenditure in Bangladesh. Indeed, the government raises their expenditure to lift the economy in the time of low inflation. On the other, it could be the case that the government increases the education expenditure in less percentage compared to an inflation rate.

As for globalization (GLOB) has very significant and negative coefficient, implying that when the total share of exports and imports as percentage of GDP increase; the total expenditure on education is decreased. This result is contradictory to the compensation theory as well as Wagner's law, which predicts that the public expenditure gradually increases due to the pressure come from international factors and influenced on social spending like the expenditure of education. This could be the case that the government of Bangladesh may allocate more budgets to other kind of public services like agriculture or health at the time of external pressure like globalization. However, the demographic variables have no significant impact on the total education expenditure as percentage of GDP.

The regression result in table 2 also demonstrates that the one-year lagged expenditure has statistically positive as well as highly significant relationships with the total education expenditure as percentage of GDP. Its coefficient of 0.673 shows the relatively high reputation of this variable. This outcome also lends support for the incrementalism theory of Charles Lindblom (1959)- inferring that the government of Bangladesh allocates its education expenditure by depending on significantly to its last budgetary practices in setting current policy on total education expenditure, with little respect for demographic factors.

As for indirect tax (IDT) that significantly as well as positively related to the total education expenditure as percentage of GDP, which implying that total education expenditure increases as the government collects more indirect taxes. This is in line with the fiscal illusion theory or voting bias model. This theory believes that as the government responsive to the needs of the 
decisive voters, that's why government must increase taxes to satisfy the growing demand for the greater benefits of the voters.

According to the fiscal illusion theory, a positive relationship between the percentage of indirect tax to total tax and the increasing public expenditure is expected; as the government tends to increase its income that is less visible to the people in order to increase its expenditure.

The last variable that significantly determines the total education expenditure as percentage of GDP is grants (GRANTS). Grants exhibit a significant but negative impact. This is contrary to the theory that support their increase will lead to an increase in public education expenditure. The public choice theory predicts that funding illusion is a provision of how a country misinterprets regarding the authentic charge of funding inflow or the spending trend close to the inflow, implying that grant false impression occurs in situation of flawed information; thereby increase government income and consequently government increase education expenditure which is not the case here in Bangladesh. It is clear that the government of Bangladesh needs to identify best ways to promote as well as make education expenditure sustainable and government can reach through the introduction of policy interferences that will enable government to effectively meet their obligation, particularly while the policy formulation along with implementation stage.

Table 3. Estimations of the Determinants of Education Expenditure: ECAP

\begin{tabular}{|c|c|c|c|c|c|c|c|}
\hline \multirow[t]{2}{*}{$\begin{array}{c}\text { Independent } \\
\text { variables }\end{array}$} & \multicolumn{2}{|c|}{$\begin{array}{l}\text { Unstandardized } \\
\text { coefficients }\end{array}$} & \multirow{2}{*}{\begin{tabular}{|c|}
$\begin{array}{c}\text { Standardized } \\
\text { coefficients }\end{array}$ \\
Beta \\
\end{tabular}} & \multirow[t]{2}{*}{$\mathrm{T}$} & \multirow[t]{2}{*}{ Sig. } & \multicolumn{2}{|c|}{$\begin{array}{c}\text { Collinearity } \\
\text { statistics }\end{array}$} \\
\hline & $\mathrm{B}$ & Std. Error & & & & Tolerance & VIF \\
\hline Constant & $\begin{array}{c}- \\
151755.313\end{array}$ & 87116.113 & & -1.742 & .115 & & \\
\hline Indirect tax & 624.965 & 241.756 & 772 & 2.585 & $.029 *$ & .147 & 6.804 \\
\hline $\begin{array}{c}\text { Total } \\
\text { population }\end{array}$ & .001 & .001 & 2.234 & 2.509 & $.033^{*}$ & .017 & 6.529 \\
\hline Inflation rate & -841.063 & 598.405 & -.244 & -1.406 & .193 & .436 & 2.296 \\
\hline Globalization & 6.047 & 12.077 & .084 & 501 & .629 & .468 & 2.135 \\
\hline $\begin{array}{c}\text { Number of } \\
\text { schools }\end{array}$ & -.670 & .152 & -1.053 & -4.402 & $.002^{*}$ & .229 & 4.368 \\
\hline Grants & 4733.460 & 12506.460 & .260 & 378 & .714 & .028 & 6.069 \\
\hline $\begin{array}{l}\text { Government } \\
\text { effectiveness }\end{array}$ & 42755.897 & 11953.689 & .608 & 3.577 & $.006^{*}$ & .454 & 2.204 \\
\hline $\begin{array}{l}\text { Democratic } \\
\text { government }\end{array}$ & -14527.862 & 4545.902 & -.478 & -3.196 & $.011^{*}$ & .585 & 1.709 \\
\hline Election year & 13435.232 & 3193.309 & .722 & 4.207 & $.002^{*}$ & .445 & 2.249 \\
\hline $\mathrm{R}^{2=0.882}$ & usted $\mathrm{R}^{2}=$ & 764 & tistic $=$ & & rbin- & atson stat & 2.514 \\
\hline
\end{tabular}

Notably for development education expenditure on education, in Table 3, first of all, number of schools $(\mathrm{SCH})$ significant but negatively related to the development expenditure on education which means that the SCH has an unclear impact on the development education expenditure. This is the case not what was expected by the Wagner's Law, nor from the Keynesian Counter-Cyclical theory arguments.

It can be said that development education expenditure allotment of Bangladesh can't be predicted by Wagner's Law or by Keynesian Counter-Cyclical theory. The development education expenditure gradually inflates not because of an up and down in the aggregate 
demand $(\mathrm{AD})$ as the economy grows. The number of schools does not affect how the policy makers make the decision about increasing the development education expenditure.

As for total population (POP) is found significantly as well as positively related to the development education expenditure which is in line with the Wagner's law, implying that with the increasing number of populations, government increases development education expenditure as the government is committed to benefits the mass along with providing more educational facilities to the people's door step.

As for democratic government (DGOV) and election cycle (ELEC), these are found significantly related to the development education expenditure despite their negative and positive coefficients (-0.478 and 0.722$)$, respectively. This case for democratic government is contradictory to Median Voter Model. It could be the case that under this research only education expenditure is taken consideration but other types of welfare expenditure like health, social safety nets may affect the development education expenditure in Bangladesh.

As in the case of election cycle in above model shows significantly as well as positive relationship with development education expenditure, which is in line with the political business cycle theory. The government of Bangladesh significantly change the development education expenditure during the election time as the government tend to satisfy the decisive voters regardless of which political party is in power.

As for government effectiveness (GE) is significant at 95 percent and positively (.608) related to the development education expenditure which is in line with the New Institutionalism theory, implying that the governance indicators, especially government effectiveness determine the policy performance level of the government; and in this case affect the development education expenditure. This type of expenditure is very much related to the performance of policy implementation as well as the level of ability of a government. Government effectiveness is positively determining development education expenditure in Bangladesh.

As for the percentage of indirect tax to total tax (IDT), it is found to be positively and significantly related to the development education expenditure, which implying that development education expenditure increases as the government collects more indirect taxes. This is in line with the fiscal illusion theory or voting bias model. This theory believes that as the government responsive to the needs of the decisive voters, that's why government must increase taxes to satisfy the growing demand for the greater benefits of the voters.

The regressions of levels of education expenditure (Tables 4, 5 and 6) also explain up to 47 , 62 and 67 percent respectively of the variation in different levels of education expenditures; almost the similar level compared to education expenditure by type. Secondary and University education both contain relatively high adjusted-R2 values, although primary education has a value of only 0.465 . 
Table 4. Estimations of the Determinants of Education Expenditure: GP

\begin{tabular}{|c|c|c|c|c|c|c|c|}
\hline $\begin{array}{c}\text { Independent } \\
\text { variables }\end{array}$ & \multicolumn{2}{|c|}{$\begin{array}{l}\text { Unstandardized } \\
\text { coefficients }\end{array}$} & $\begin{array}{c}\text { Standardized } \\
\text { coefficients }\end{array}$ & \multirow[t]{2}{*}{$\mathrm{T}$} & \multirow[t]{2}{*}{ Sig. } & \multicolumn{2}{|c|}{$\begin{array}{c}\text { Collinearity } \\
\text { statistics }\end{array}$} \\
\hline & B & Std. Error & Beta & & & Tolerance & VIF \\
\hline Constant & 639606.256 & 601624.421 & & 1.063 & .296 & & \\
\hline $\begin{array}{c}\text { Lagged } \\
\text { expenditure }\end{array}$ & 18.082 & 10.197 & 693 & 1.773 & .087 & .095 & 10.553 \\
\hline Globalization & -777.032 & 828.010 & -.187 & -.938 & .356 & .366 & 2.731 \\
\hline Inflation rate & -7962.519 & 15045.738 & -.093 & -.529 & .601 & .468 & 2.139 \\
\hline $\begin{array}{c}\text { Total } \\
\text { population }\end{array}$ & .007 & .003 & .621 & 2.115 & $.043^{*}$ & .168 & 5.958 \\
\hline $\begin{array}{l}\text { Number of } \\
\text { schools }\end{array}$ & -30.774 & 8.862 & -.851 & -3.473 & $.002^{*}$ & 241 & 4.156 \\
\hline $\begin{array}{l}\text { Democratic } \\
\text { government }\end{array}$ & -62371.183 & 165342.113 & -.099 & -.377 & .709 & 212 & 4.719 \\
\hline Election year & 29039.865 & 98672.702 & .038 & 294 & .771 & 856 & 1.169 \\
\hline $\begin{array}{c}\text { Student- } \\
\text { teacher ratio }\end{array}$ & -783.614 & 2199.488 & -.073 & -.356 & .724 & 347 & 2.882 \\
\hline $\mathrm{R}^{2}=0.580$ & & 465 & 5.016 & & & stat $=$ & \\
\hline
\end{tabular}

In table 4, the coefficient estimate of $\mathrm{SCH}$ is very significant but negative, which is contradictory to the theory of Wagner's Law as well as the Keynesian Counter-Cyclical theory arguments and in this case shows the similar results to the case of development education expenditure discussed above. The government of Bangladesh do not take under consideration the number of schools in allocating the primary education expenditure policy.

The estimated coefficient of total population (POP) in the primary education expenditure shown in table 4, is statistically significant as well as positive, which is in line with the Wagner's Law, implying that with the increasing number of populations, government increases the primary education expenditure as it is the universal education and government wants to make affordable for every one this levels of education. Particularly interesting, the fact that primary education expenditure is not determined by any economic, political, governance, or even incrementalism factors.

Table 5. Estimations of the Determinants of Education Expenditure: GS

\begin{tabular}{|c|c|c|c|c|c|c|c|}
\hline \multirow[t]{2}{*}{$\begin{array}{c}\text { Independent } \\
\text { variables }\end{array}$} & \multicolumn{2}{|c|}{$\begin{array}{l}\text { Unstandardized } \\
\text { coefficients }\end{array}$} & \multirow{2}{*}{\begin{tabular}{|c|}
$\begin{array}{c}\text { Standardized } \\
\text { coefficients }\end{array}$ \\
Beta
\end{tabular}} & \multirow[t]{2}{*}{$\mathrm{T}$} & \multirow[t]{2}{*}{ Sig. } & \multicolumn{2}{|c|}{$\begin{array}{c}\text { Collinearity } \\
\text { statistics }\end{array}$} \\
\hline & $\bar{B}$ & Std. Error & & & & Tolerance & VIF \\
\hline Constant & $\begin{array}{c}\cdot \\
518260.558\end{array}$ & 794477.447 & & -.652 & .519 & & \\
\hline $\begin{array}{c}\text { Lagged } \\
\text { expenditure }\end{array}$ & -27.979 & 13.424 & -.787 & -2.084 & $.046^{*}$ & .072 & 13.820 \\
\hline Globalization & 5281.064 & 983.085 & .930 & 5.372 & $.000^{* *}$ & 344 & 2.909 \\
\hline Inflation rate & 18685.228 & 16930.409 & .160 & 1.104 & .279 & 489 & 2.046 \\
\hline $\begin{array}{c}\text { Total } \\
\text { population }\end{array}$ & .017 & .005 & 1.087 & 3.406 & $.002^{*}$ & .101 & 9.888 \\
\hline $\begin{array}{l}\text { Number of } \\
\text { schools }\end{array}$ & -11.244 & 10.185 & -.228 & -1.104 & 279 & .241 & 4.147 \\
\hline $\begin{array}{l}\text { Democratic } \\
\text { government }\end{array}$ & 98245.335 & 181273.414 & .114 & .542 & .592 & .233 & 4.286 \\
\hline Indirect tax & -16253.082 & 6383.596 & -.393 & -2.546 & $.016^{*}$ & 432 & 2.313 \\
\hline Grants & 11642.910 & 9919.705 & 203 & 1.174 & .250 & 346 & 2.894 \\
\hline$R^{2}=0.701$ & justed $R^{2}=$ & F-sta & istic $=8.501$ & & in-Wa & n stat $=1$ & \\
\hline
\end{tabular}

In table 5, secondary education expenditure is statistically and positively determined by total 


\section{Ml Macrothink

population (POP) and globalization (GLOB). The estimated coefficient of total population (POP) is (1.087) positive and highly significant at 95 percent. In this case the number of total populations is significantly related to the secondary education expenditure as like as the development and primary education expenditure. This is the case, which is in line with the Wagner's law, implying that with the increasing number of populations, government increases the secondary education expenditure.

As for the economic variable globalization (GLOB), the estimated coefficient is (0.930) significantly positive and highly significant at more than 99 percent. In this case, the pressure from globalization (Sum of Exports and Imports as \% to the GDP) compels the government to increase the budgetary allocation in the secondary education expenditure positively. This is the case in line with the compensation as well as Wagner's Law. The secondary level of education is very important stage in Bangladesh as the more human capital add in human resources after completing the secondary level of education and contributes a lot in the economic as well as social development of a country.

As for the indirect tax (IDT), in terms of the impact of the political factors, it is the only variable in this model that has a significant impact on the secondary education expenditure. The estimated negative coefficient (-.393) of the indirect tax indicates that as indirect tax increases, the secondary education expenditure seems to be decreased. This is the case, however, contradicts the fiscal illusion model of public choice theory. It thus may be fairly surprising that this variable is one of the determinants of the secondary education expenditure.

The estimated coefficient of the incrementalist variable in secondary education expenditure is negative (-.787) but statistically significant, which is little bit contradictory with the theoretical expectation. The impact of this variable, with its highly negative coefficient value of -.787, indicating the arbitrary impact, implying that incrementatist variable decreases the secondary education expenditure significantly. Arguably from this result, the government's budgetary allocation to secondary education expenditure has been strongly influenced but not determined by the last year's budget. 
Table 6. Estimations of the Determinants of Education Expenditure: GU

\begin{tabular}{|c|c|c|c|c|c|c|c|}
\hline \multirow[t]{2}{*}{$\begin{array}{c}\text { Independent } \\
\text { variables } \\
\end{array}$} & \multicolumn{2}{|c|}{$\begin{array}{c}\text { Unstandardized } \\
\text { coefficients }\end{array}$} & \multirow{2}{*}{$\begin{array}{c}\begin{array}{c}\text { Standardized } \\
\text { coefficients }\end{array} \\
\text { Beta } \\
\end{array}$} & \multirow[t]{2}{*}{$\mathrm{T}$} & \multirow[t]{2}{*}{ Sig. } & \multicolumn{2}{|c|}{$\begin{array}{c}\text { Collinearity } \\
\text { statistics }\end{array}$} \\
\hline & $\mathrm{B}$ & Std. Error & & & & Tolerance & VIF \\
\hline Constant & $\begin{array}{c}- \\
314502.308 \\
\end{array}$ & 349375.322 & & -.900 & .376 & & \\
\hline $\begin{array}{c}\text { Lagged } \\
\text { expenditure }\end{array}$ & -16.518 & 5.822 & -.996 & -2.837 & $.008 *$ & .072 & 13.826 \\
\hline Globalization & 2939.900 & 433.481 & 1.110 & 6.782 & $.000^{* * *}$ & .332 & 3.009 \\
\hline Inflation rate & 10807.900 & 7534.462 & .199 & 1.434 & 163 & .464 & 2.156 \\
\hline $\begin{array}{c}\text { Total } \\
\text { population }\end{array}$ & .007 & .002 & .975 & 3.267 & $.003^{*}$ & .100 & 10.007 \\
\hline $\begin{array}{c}\text { Number of } \\
\text { schools }\end{array}$ & -1.294 & 4.447 & -.056 & -.291 & .773 & .238 & 4.206 \\
\hline $\begin{array}{l}\text { Democratic } \\
\text { government }\end{array}$ & 69273.992 & 78609.328 & .172 & .881 & .386 & .233 & 4.287 \\
\hline Indirect tax & -8332.284 & 2784.363 & -.432 & -2.993 & $006^{*}$ & .427 & 2.341 \\
\hline Grants & 6263.917 & 4370.395 & .234 & 1.433 & 163 & .335 & 2.988 \\
\hline Election year & 27143.355 & 50413.529 & .056 & .538 & .595 & 815 & 1.226 \\
\hline$R^{2}=0.751$ & djusted $\mathrm{R}^{2}=$ & .671 & istic $=9.368$ & & rbin-V & tson stat & 1.777 \\
\hline
\end{tabular}

As for university education, as shown in table 6 , the value of adjusted- $\mathrm{R}^{2}$ is relatively high and the explanation of this model is sound. As for the economic variable globalization (GLOB), the estimated coefficient is significantly positive (1.110) and highly significant at more than 99 percent. In this case, the pressure from globalization compels the government to increase the budgetary allocation in the university education expenditure positively as like as the secondary education expenditure. This is the case in line with the compensation as well as Wagner's Law. The university level of education is very important stage in Bangladesh as the more human capital added in human resources after completing the university level of education and contributes a lot in the socio-economic as well as political development of a country.

The estimated coefficient of total population (POP) in the university education expenditure, shown in table 6 , is statistically significant as well as positive, which is in line with the Wagner's Law, implying that with the increasing number of populations, government increases the higher education expenditure as it is the specialized education and government wants to make affordable for every one this levels of education. Particularly interesting, the fact that university education expenditure is not determined by any, economic, governance, or even incrementalism factors.

As for the indirect tax (IDT), in terms of the impact of the political factors, it is the only variable in this model that has a significant impact on the university education expenditure. The estimated negative coefficient (-.432) of the indirect tax indicates that as indirect tax increases, the university education expenditure seems to be decreased. This is the case, however, contradicts the fiscal illusion model of public choice theory. It thus may be fairly surprising that this variable is one of the determinants of the university education expenditure.

The estimated coefficient of the incrementalist variable in university education expenditure is negative (-.996) but statistically significant, which is little bit contradictory with the 


\section{Macrothink}

Journal of Public Administration and Governance

ISSN 2161-7104

2019, Vol. 9, No. 3

theoretical expectation. The impact of this variable, with its highly negative coefficient value of -.996, indicating the arbitrary impact, implying that incrementatist variable decreases the university education expenditure significantly. Arguably from this result, the government's budgetary allocation to university education expenditure has been strongly influenced but not determined by the last year's budget.

\subsection{The Goodness of Fit}

In the figure 2, the trend of actual total education expenditure as percentage of GDP is plotted along with the predicted total education expenditure as percentage of GDP extracted from table 2. The goodness of fit of the predicted total education expenditure as percentage of GDP is pretty harmonized with the actual data, indicating that this model is quite robust, except for a little bit deviation from the actual levels of data observed from 1994-1996, 2013-2014 and 2018 respectively. This trend inlying the strength of the estimation from the total education expenditure as percentage of GDP model. So, this can be taken under consideration as an exact prediction of the trend of total education expenditure in Bangladesh. Furthermore, each variable can explain the drive of total education expenditure as percentage of GDP fairly sound.

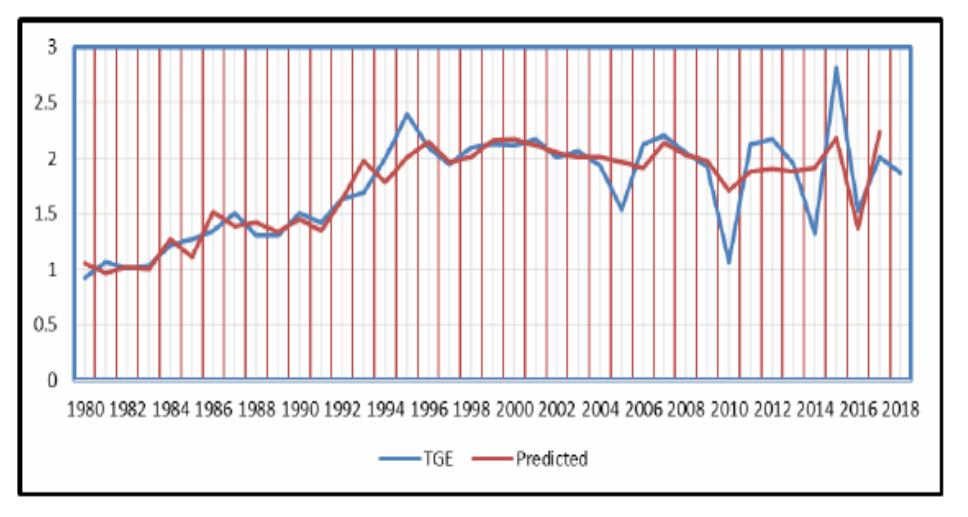

Figure 2.The Goodness of Fit of the Total Education Expenditure as Percentage of GDP

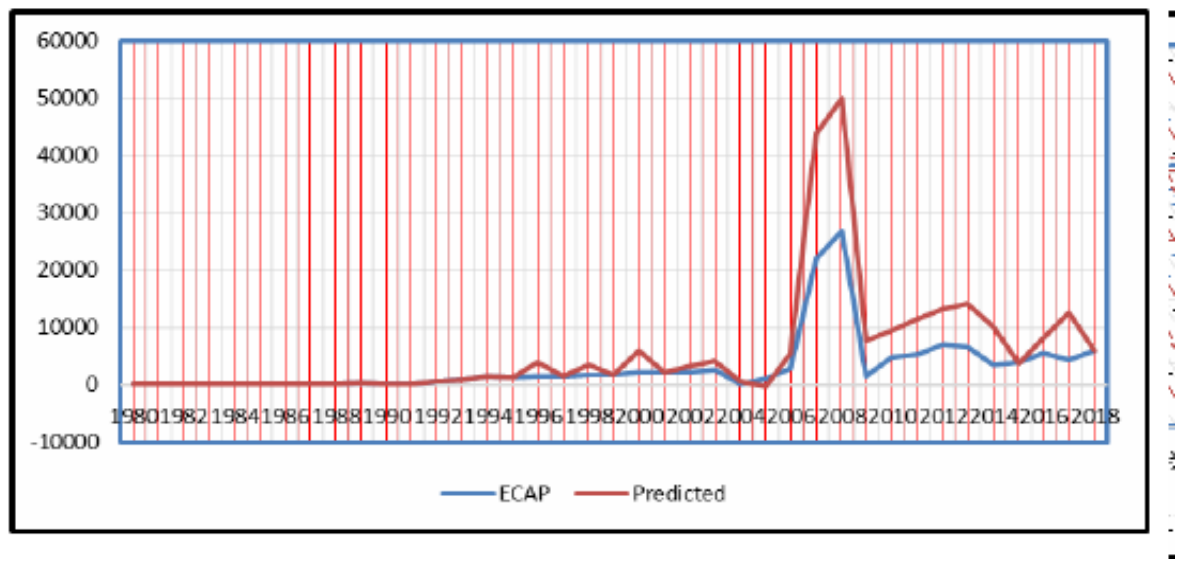

Figure 3.The Goodness of Fit of the Development Education Expenditure

The goodness of fit of the development education expenditure shown in figure 3 


\section{Macrothink}

demonstrates the goodness of fit, drawn from table 3, which seems reasonable though there are some fluctuations as well as deviation from the actual levels observed during 2002 to 2004 and 2014 to 2017. As the data of governance indicators like, governance effectiveness is unavailable up to 1996 and 1997, 1999 as well as 2001, hence the SPSS, version 23 can't predict the value of control of corruption which is included in the development education expenditure model.

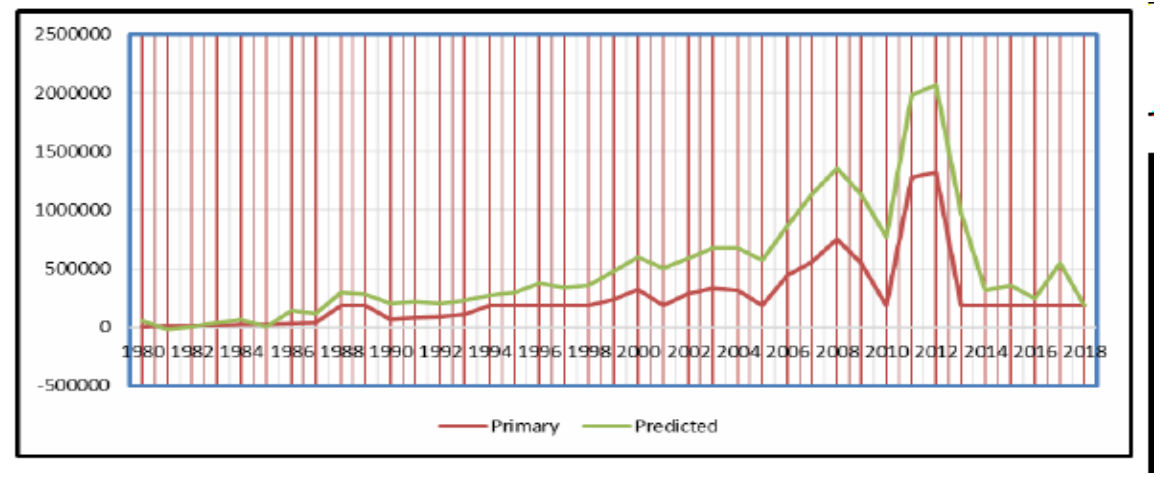

Figure 4. The Goodness of Fit of the Primary Education Expenditure

The above figure 4, the model fits the observation very well. The two lines- the prediction as well as actual lines are almost matched at the same point along with the observation period of 1980 to 2018, except a little bit deviation in the year of 2016-2017. In addition, there is no noticeable deviation or fluctuation of the prediction from the actual line. This result implying that the robustness of this model is high. This is further confirmed by the value of adjusted- $\mathrm{R}^{2}$, which is almost 47 percent. The comparison between the actual value as well as the value predicted by the model are nearly identical, as seen from the line graph.

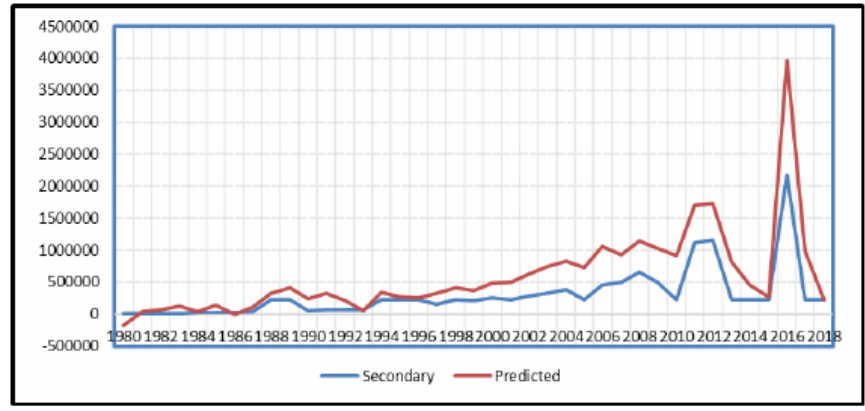

Figure 5. The Goodness of Fit of the Secondary Education Expenditure

The figure 5, the model fits of the observation very well. The value of two lines- the prediction as well as actual lines are almost matched at the same point along with the review period of 1980 to 2018, except a minor deviation in the year of 2006-2007. In addition, there is no obvious deviation or fluctuation of the prediction from the actual line. This result implying that the robustness of this model is very high. This is further confirmed by the value of adjusted- $\mathrm{R}^{2}$, which is 62 percent. The comparison between the actual value as well as the value predicted by the model are nearly identical, as seen from the line graph. 


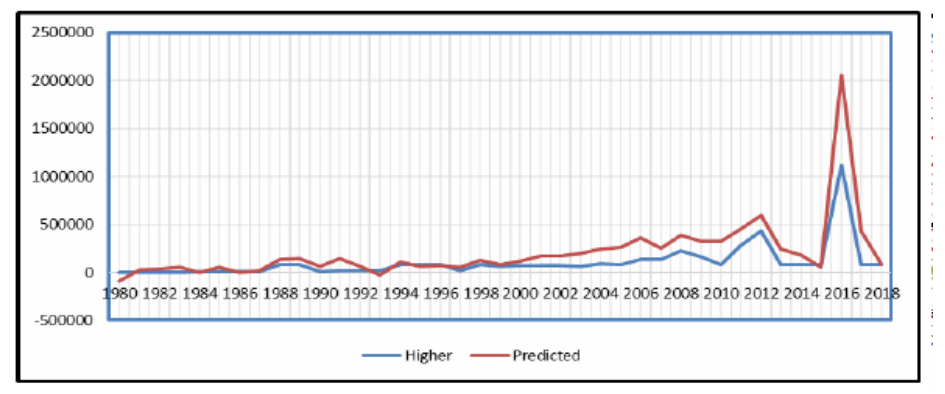

Figure 6. The Goodness of Fit of the University Education Expenditure

The figure 6 drawn from table 6 , indicates that the prediction as well as the actual lines are very well matched at the same points during the time period under review of 1980 to 2018 for university education expenditure model. In this scenario, the predicted values of this model are rationally well-fitted, with the actual value as seen in the figure 6 . This scenario goes in line with the high adjusted- $\mathrm{R}^{2}$ value of 0.671 . This goodness of fit model contains only minor deviation at the year of 1991 to 1993 and 2017-2018 which is as like as secondary education expenditure model. This also same as to the pattern that appeared to the secondary education expenditure model.

Overall, among the goodness of fit in the five models, Model 1, 2, 3, 4 and 5, which represent the estimation for total, development, primary, secondary, and university education expenditure respectively, have confirmed a robust estimation along with sound prediction of each type and levels of education expenditures.

Table 7.Summary of the Determinants of Education Expenditures at the Macro-Level

\begin{tabular}{|c|c|c|}
\hline Expenditures & Determinants & Signs \\
\hline Total Education expenditure as & Lagged expenditure & + \\
percentage of GDP & Indirect Tax & + \\
& Inflation rate & - \\
& Globalization & - \\
\hline Gevelopment Education & Number of Schools & - \\
Expenditure & Democratic Government & - \\
& Election Cycle & + \\
& Government Effectiveness & + \\
& Total Populations & + \\
\hline Indirect Tax & + \\
\hline Primary Education & Total Populations & - \\
Expenditure & Number of Schools & + \\
Expenditure & Total Populations & + \\
& Globalization & - \\
\hline Higher Education Expenditure & Lagged Expenditure & - \\
& Indirect Tax & + \\
& Total Population & - \\
& Globalization & - \\
\hline
\end{tabular}

The model of primary education expenditure is relatively less robust as well as the predictions little bit deviate along with fluctuation from the actual data.

\section{Conclusions and Policy Recommendations}

This research has endeavored to gain understanding, concerning the actual behavior of the government of Bangladesh on education expenditure policy. In the contemporary literature, this kind of study is really rare and only Brazil, Thailand, Kenya and Argentina are the example of this types of study. Maximum of the earlier studies pay head to the total budget of the government or the cross-country analysis along with focusing on the total expenditure as 
part of education expenditures. This research can thus significantly complement to the literature by investigating in detail the case of Bangladesh as well as by exploring the determinants of different types and levels of education expenditures.

No doubt that the education expenditures in Bangladesh have increased significantly over the study period. The fundamental reason of this trend is the policy decision that follows the five-year plans, MDGs and strategic plan. All the plans make concentration on the role of human capital development, and education is alleged to be lift it.

Specially, total and development expenditure is considered as types as well as primary, secondary and university or tertiary education as different levels of education expenditures. Under this research, these education expenditures are considered as dependent variables, which then explained by a set of multidimensional predictor variables, like economic-demographic, decision- making, political as well as governance indicators. Even though, this research is policy oriented by nature, there are some theoretical contributions along with policy recommendations.

Overall, the allocation of education expenditure in Bangladesh is not best explained by one single variable or theory. Last year's expenditure and indirect tax is the best predictor of the total education expenditure as percentage of GDP, and these are statistically and positively significant. University education expenditure is negatively affected by the indirect tax. Wagner's law and fiscal illusion theory also illustrate well how public education expenditure in Bangladesh is determined. This may be the inefficiency and policy gap of the government of Bangladesh in allocating education expenditure properly.

Number of schools has effects on one type and levels of education: development and primary education expenditures. Both are negatively determined by number of schools, which is contradictory to the Wagner's Law as well as Keynesian Counter-Cyclical theory arguments. Globalization also increases some levels of education expenditure, including secondary and university education expenditure, with GLOBs coefficients of 0.739 and 0.851 , respectively. These leads support to Compensation theory. Conversely, total education expenditure is decreases by the globalization having coefficient of -.410 which contradicts with the Compensation theory. This may be the case that the government is not concern about education factors for allocating education expenditure as well as totally depends on the performance of the imports and exports in the international markets. This is also the sign of inefficient policy regarding education expenditure.

The estimation of inflation's impact supports the Keynesian Counter-Cyclical theory, which applies only the case of total education expenditure. The effects of inflation found in this research, though, counter Wagner's law. The fiscal illusion theory is not perfectly applicable in the case of Bangladesh because, IDT is positively related to total and development education expenditure and negatively related to the secondary and university education expenditure.

The estimation of total population's impact supports the Wagner's law which applies in the case of type and levels of education like development, primary, secondary and university 
education expenditures. Election cycle estimation also supports the political business cycle theory. The government of Bangladesh change the development education expenditure during the election year.

The estimation of government effectiveness's impact supports the new institutionalism theory which applies in the case of development education expenditure as it is very important determinant in allocation of the overall expenditure of education development.

As for policy recommendation, this research shows that the total education expenditure budget depends on last year's budget, the economic-demographic, political and governance factors which are total populations, globalization, indirect tax and government effectiveness. Bangladesh seems not to have problem of more spending in education, but the concern is efficiency, transparency and accountability in terms of allocation in this kind of budget. Outstandingly, improving the budget of education expenditure in making it further approachable to the demographic demand, especially the education indicators and economic indicators, would help the students the most in terms of resources distribution. Fiscal reform, thus, needs a more approachable education expenditure policy along with participation from concern agencies as well as the public, which can expand resource sharing in Bangladesh. Governance issues should take into consideration while implementing education program effectively. If the government of Bangladesh pay more head to governance issues, it may create exemplary performance level in the world to the education expenditure. Additionally, government should consider rising education expenditure in high inflation time to continue the same level of educational standards.

For future study, a more micro-level investigation of education expenditure in Bangladesh can and would offer a better understanding of its determinants. This study gives discussion only on public education expenditure of formal education, not included the private and non-formal education expenditure. Taking into consideration the per-student expenditure in levels of education also leads to an issue of quality education. Also, while this study focuses on the determinants of public education expenditure, the effect of this type of expenditure would further be vital for human capital development as well as the efficiency of fiscal policy. Additional research of these kinds must be appreciated.

\section{References}

Alesina, A., \& Roubini, N. (1992). Political Cycles in OECD Economies. The Review of Economic Studies, 59(4), 663-688. Retrieved from https://www.jstor.org/stable/2297992

Balcells, V. L. (2006). Trade Openness and Preferences for Redistribution: A Cross-National Assessment of the Compensation Hypothesis. Business and Politics, 8(2), 1-50. https://doi.org/10.2202/1469-3569.1131

Borcherding, T. E. (Ed.). (1977). Budgets and Bureaucrats: The Sources of Government Growth. North Carolina: Duke University Press Durham.

Buchanan, J. M. (1975). The Limits of Liberty. Chicago: The University of Chicago Press. Buchanan, J. M., \& Tullock, G. (1977). The expanding public sector: Wagnor sqaured. Public Choice, 31(Fall), 147-150.

Buchanan, J. M., \& Wagner, R. E. (1977). Democracy in Deficit The Political Legacy of Lord 
Keynes. New York: Academic press.

Buracom, P. (2011). Explaining the growth and distributional and fiscal effects of public education, health, and welfare spending in Thailand. Asian Affairs: An American Review, 38(3), 113-142.

Busemeyer, M. R. (2007). Determinants of public education spending in 21 OECD democracies, 1980-2001. Journal of European Public Policy, 14(4), 582-610. https://doi.org/10.1080/13501760701314417

Dye, T. R. (1978). Understanding Public Policy (3rd ed.). Prentice- Hall, Inc.

Dye, T. R. (2005). Understanding Public Policy (11th ed.). New Jersey: Pearson Education, Inc.

Easton, D. (1965). A Systems Analysis of Political Life. New York: John Wiley \& Sons, Inc.

Etzioni, A. (1967). Mixed-Scanning: A "Third" Aproach to Decision-making. American Society for Public Administration, 27(5), 385-392. https://doi.org/10.1007/s10869-007-9037-x Fernandez, R., \& Rogerson, R. (1997). The Determinants of Public Education Expenditures: Evidence from the States, 1950-1990 (NBER Working Paper Series No. 5995). Cambridge, MA.

Ferris, J. S., \& West, E. G. (1999). Cost disease versus Leviathan explanations of rising government cost: An empirical investigation. Public Choice, 98(3-4), 307-316. Retrieved from http://search.proquest.com/docview/207157775? accountid=25704

Garrett, G. (2000). The Causes of Globalization. Comparative Political Studies, 33(6/7), 941-991.

Garrett, G., \& Mitchell, D. (2001). Globalization, government spending and taxation in the OECD. European Journal of Political Research, 39(2), 145-177. https://doi.org/10.1023/A:1011043120145

Hanushek, E. A., \& Rivkin, S. G. (1997). Understanding the Twentieth-Century growth in U.S. School Spending. The Journal of Human Resources, xxx11(1), 35.

Henrekson, M. (1988). Sweedish Government Growth: A Disequilibrium Analysis. In J. . Lybeck \& M. Henreckson (Eds.), Explaining The Growth of Government (pp. 93-132). New York: Elsevier Science B.V.

Heyndels, B., \& Smolders, C. (1994). Fiscal Illusion at the Local Level : Empirical Evidence for the Flemish Municipalities. Public Choice, 80(3/4), 325-338. Retrieved from https://www.jstor.org/stable/30027088

Hibbs, D. A. (1994). the Partisan Model of Macroeconomic Cycles: More Theory and Evidence for the United States. Economics \& Politics, 6(1), 1-23. https://doi.org/10.1111/j.1468-0343.1994.tb00081.x

Kemnitz, A. (1999). Demographic Structure and the Political Economy of Education Subsidies. Public Choice, 101(3), 235-249.

Lindblom, C. E. (1959). The Science of "Muddling Through.” American Society for Public Administration (Vol. 19). Retrieved from http://www.jstor.org/stable/973677

Mankiw, N. G. (2010). Intermediate Macroeconomics (7th ed.). Worth Palgrave Macmillan. Marshall, L. (1991). New Evidence of Fiscal Illusion: The 1986 tax "Windfalls." American Economic Review, 81(5), 1336-1344.

Meltzer, A. H., \& Richard, S. F. (1983). Tests of a Rational Theory of the Size of Government. 
Springer, 41(3), 403-418. Retrieved from https://www.jstor.org/stable/30023711

Mueller, D. C. (1987). The Growth of Government: A Public Choice Perspectives. Staff Papers (International Monetary Fund, 34(1), 115-149. Retrieved from https://www.jstor.org/stable/3867026

Niskanen Jr, W. A. (1971). Bureaucracy and Representative Government. Chicago: Aldine. Atherton.

Oates, W. (1988). On the Nature and Measurement of Fiscal Illusion: A Survey. Taxation and Fiscal Federalism: Essays in Honor of Russell Mathews, 65-82.

Peltzman, S. (1980). The Growth of Government. The Journal of Law and Economics, 1. https://doi.org/10.1533/9781845699789.5.663

Quade, E. (1982). Analysis for Public Decisions (2nd ed.). New York: Elsevier Science Publishing.

Ram, R. (1995). Public educational expenditures in the United States: An analytical comparison with other industrialized countries. Economics of Education Review, 14(1), 53-61. https://doi.org/10.1016/0272-7757(94)00029-6

Rodrik, D. (1998). Why do More Open Economies Have Bigger Governments ? Journal of Political Economy, 106(5), 997-1032. Retrieved from https://www.jstor.org/stable/10.1086/250038

Romer, T., \& Rosenthal, H. (1978). Political Resource Allocation, Controlled Agendas, and the Status Quo. Public Choice, 33(4), 27-43. Retrieved from https://www.jstor.org/stable/30023066

Saeki, M. (2005). Systematic, political, and socioeconomic influences on educational spending in the American States. Review of Policy Research, 22(2), 245-256. https://doi.org/10.1111/j.1541-1338.2005.00132.x

Sagarik, D. (2013). An Analysis of the Determinants of Education Expenditure in Thailand. Asian Politics \& Policy, 5(2), 227-248.

Tandberg, D. (2009). Interest Groups and Governmental Institutions. Educational Policy, 24(5), 735-778. https://doi.org/10.1177/0895904809339163

Tandberg, D. (2010). Interest Groups and Governmental Institutions. Educational Policy, 24(5), 735-778. https://doi.org/10.1177/0895904809339163

Tanzi, V., \& Schuknecht, L. (2000). Public Spending in The 20th Centure (1st ed., p. 291). United kingdom: Cambridge University Press.

Ubiergo, A. S. (2007). The Political Economy of the Welfare State in Latin America Globalization, Democracy, and Development. New York: Cambridge University Press. Retrieved from www.cambridge.org

Wagner, A. (1958). Three Extracts on Public Finance. In R. A. Musgrave \& A. T. Peacock (Eds.), Classics in the Theory of Public Finance (p. 244). New York: Macmillan.

Yoon, J. (2009). Globalization and the Welfare State in Developing Countries. Business and Politics, 11(2). https://doi.org/10.2202/1469-3569.1205 
Appendix: A

Table 1. Dependent Variables

\begin{tabular}{|c|c|c|c|c|c|}
\hline Year & TGE & ECAP & GU & GS & GP \\
\hline 1980 & 0.93 & 75.77 & 3855.82 & 4250.38 & 7088.26 \\
\hline 1981 & 1.07 & 73.92 & 4030.36 & 8601.49 & 11069.77 \\
\hline 1982 & 1.01 & 90.25 & 3507.06 & 9865.28 & 11937.69 \\
\hline 1983 & 1.03 & 126.46 & 4331.74 & 13541.87 & 18568.06 \\
\hline 1984 & 1.22 & 128.44 & 5644.81 & 20081.32 & 22106.58 \\
\hline 1985 & 1.27 & 163.47 & 5834.45 & 20210.62 & 26647.53 \\
\hline 1986 & 1.34 & 211.94 & 6786.21 & 24281.77 & 34664.94 \\
\hline 1987 & 1.51 & 281.28 & 9047.48 & 44909.69 & 39019.87 \\
\hline 1988 & 1.30 & 260.95 & 78315.72 & 219654.36 & 182577.10 \\
\hline 1989 & 1.30 & 358.61 & 78315.72 & 219654.36 & 182577.10 \\
\hline 1990 & 1.51 & 170.00 & 12399.29 & 58277.72 & 70184.05 \\
\hline 1991 & 1.42 & 170.08 & 14764.51 & 63434.74 & 80020.14 \\
\hline 1992 & 1.63 & 593.00 & 19827.78 & 62474.79 & 96028.66 \\
\hline 1993 & 1.69 & 892.00 & 16796.64 & 73618.25 & 106118.40 \\
\hline 1994 & 2.00 & 1603.00 & 78315.72 & 219654.36 & 182577.10 \\
\hline 1995 & 2.40 & 1370.00 & 78315.72 & 219654.36 & 182577.10 \\
\hline 1996 & 2.10 & 1551.00 & 78315.72 & 219654.36 & 182577.10 \\
\hline 1997 & 1.95 & 1542.00 & 17304.10 & 160552.94 & 187370.86 \\
\hline 1998 & 2.10 & 1751.00 & 78315.72 & 219654.36 & 182577.10 \\
\hline 1999 & 2.13 & 1751.00 & 59374.73 & 205046.63 & 240856.65 \\
\hline 2000 & 2.12 & 2064.00 & 71228.55 & 254239.89 & 327363.75 \\
\hline 2001 & 2.17 & 2252.00 & 70459.34 & 219654.36 & 182577.10 \\
\hline 2002 & 2.01 & 2138.00 & 71160.24 & 279531.79 & 288152.35 \\
\hline 2003 & 2.06 & 2541.00 & 66218.43 & 330443.86 & 330198.03 \\
\hline 2004 & 1.94 & 228.30 & 90739.30 & 381058.42 & 314365.02 \\
\hline 2005 & 1.54 & 1065.38 & 78315.72 & 219654.36 & 182577.10 \\
\hline 2006 & 2.13 & 2755.10 & 136965.17 & 460050.39 & 444522.93 \\
\hline 2007 & 2.20 & 21883.25 & 138686.14 & 493206.18 & 559355.65 \\
\hline 2008 & 2.05 & 26963.77 & 221868.54 & 662214.92 & 757601.77 \\
\hline 2009 & 1.93 & 1430.80 & 166544.74 & 495951.75 & 551736.44 \\
\hline 2010 & 1.07 & 4893.00 & 78315.72 & 219654.36 & 182577.10 \\
\hline 2011 & 2.13 & 5213.00 & 279086.76 & 1115572.43 & 1278037.60 \\
\hline 2012 & 2.17 & 7128.10 & 435202.38 & 1154919.82 & 1317491.85 \\
\hline 2013 & 1.96 & 6634.50 & 78315.72 & 219654.36 & 182577.10 \\
\hline 2014 & 1.32 & 3490.83 & 78315.72 & 219654.36 & 182577.10 \\
\hline 2015 & 2.82 & 3987.68 & 78315.72 & 219654.36 & 182577.10 \\
\hline 2016 & 1.53 & 5409.99 & 1122648.45 & 2170183.20 & 182577.10 \\
\hline 2017 & 2.01 & 4355.31 & 78315.72 & 219654.36 & 182577.10 \\
\hline 2018 & 1.87 & 6014.17 & 78315.72 & 219654.36 & 182577.10 \\
\hline
\end{tabular}




\section{Appendix: B}

Table 2. Independent Variables (Economic-Demographic factors)

\begin{tabular}{|c|c|c|c|c|c|c|c|c|c|}
\hline Year & GDP & INF & POP & URB & GLOB & UNEM & $\mathrm{SCH}$ & GEN_P & STR_P \\
\hline 1980 & 222.63 & 17.55 & 81470860 & 14.85 & 23.37 & 3.21 & 36957.0 & 70.54 & 53.56 \\
\hline 1981 & 241.87 & 9.89 & 83721268 & 15.80 & 19.24 & 3.21 & 36953.0 & 69.30 & 55.27 \\
\hline 1982 & 215.39 & 9.85 & 86007331 & 16.21 & 20.60 & 3.21 & 36952.0 & 70.49 & 44.62 \\
\hline 1983 & 199.33 & 8.48 & 88338242 & 16.63 & 20.31 & 1.80 & 36959.0 & 71.68 & 51.40 \\
\hline 1984 & 208.53 & 7.87 & 90732362 & 17.06 & 16.81 & 1.80 & 36956.0 & 70.14 & 46.95 \\
\hline 1985 & 239.03 & 18.49 & 93199865 & 17.49 & 18.22 & 1.10 & 36999.0 & 67.94 & 46.97 \\
\hline 1986 & 227.42 & 8.25 & 95742431 & 17.94 & 17.01 & 1.00 & 37101.0 & 67.33 & 47.84 \\
\hline 1987 & 247.07 & 11.11 & 98343809 & 18.39 & 16.68 & 3.21 & 37102.0 & 66.12 & 48.08 \\
\hline 1988 & 263.22 & 7.49 & 100975321 & 18.85 & 17.67 & 3.21 & 38077.0 & 77.65 & 57.87 \\
\hline 1989 & 277.81 & 8.33 & 103599232 & 19.33 & 18.32 & 1.20 & 38126.0 & 77.61 & 60.39 \\
\hline 1990 & 297.56 & 6.53 & 106188642 & 19.81 & 16.70 & 1.90 & 38158.0 & 80.89 & 63.00 \\
\hline 1991 & 284.72 & 2.72 & 108727432 & 20.25 & 17.60 & 2.20 & 38184.0 & 75.60 & 78.97 \\
\hline 1992 & 285.09 & 2.58 & 111221938 & 20.61 & 20.10 & 2.29 & 38615.0 & 91.70 & 82.13 \\
\hline 1993 & 291.71 & 3.30 & 113695139 & 20.96 & 19.90 & 2.41 & 38572.0 & 91.70 & 89.03 \\
\hline 1994 & 290.65 & 8.90 & 116182267 & 21.32 & 24.50 & 2.51 & 38575.0 & 91.70 & 95.47 \\
\hline 1995 & 319.60 & 6.70 & 118706871 & 21.69 & 26.40 & 2.60 & 38562.0 & 92.00 & 108.68 \\
\hline 1996 & 382.93 & 3.96 & 121269645 & 22.06 & 27.30 & 2.50 & 38574.0 & 95.00 & 109.19 \\
\hline 1997 & 389.52 & 8.66 & 123854640 & 22.43 & 28.80 & 2.71 & 38271.0 & 95.60 & 111.68 \\
\hline 1998 & 395.29 & 7.06 & 126447965 & 22.81 & 29.10 & 2.93 & 38274.0 & 96.20 & 116.17 \\
\hline 1999 & 397.35 & 2.79 & 129029691 & 23.20 & 30.00 & 3.12 & 38275.0 & 96.30 & 117.85 \\
\hline 2000 & 405.60 & 1.94 & 131581243 & 23.59 & 33.60 & 3.26 & 38261.0 & 96.60 & 111.67 \\
\hline 2001 & 402.59 & 2.79 & 134107160 & 24.09 & 30.60 & 3.40 & 38259.0 & 97.50 & 108.95 \\
\hline 2002 & 400.61 & 4.38 & 136600667 & 24.75 & 31.20 & 3.55 & 38259.0 & 97.30 & 108.09 \\
\hline 2003 & 432.73 & 5.83 & 139019001 & 25.42 & 32.80 & 4.32 & 38259.0 & 104.10 & 65.08 \\
\hline 2004 & 460.75 & 6.48 & 141307489 & 26.11 & 36.30 & 4.36 & 38263.0 & 101.60 & 65.08 \\
\hline 2005 & 484.15 & 7.17 & 143431101 & 26.80 & 38.30 & 4.25 & 38267.0 & 98.47 & 47.04 \\
\hline 2006 & 494.05 & 7.22 & 145368004 & 27.51 & 48.90 & 3.58 & 38267.0 & 99.18 & 47.54 \\
\hline 2007 & 541.06 & 9.93 & 147139191 & 28.23 & 42.00 & 3.91 & 38264.0 & 98.36 & 44.75 \\
\hline 2008 & 615.77 & 6.66 & 148805814 & 28.96 & 40.10 & 4.23 & 38275.0 & 96.27 & 43.73 \\
\hline 2009 & 681.12 & 7.71 & 150454708 & 29.70 & 39.90 & 5.00 & 38276.0 & 99.46 & 45.76 \\
\hline 2010 & 757.67 & 10.91 & 152149102 & 30.46 & 42.90 & 3.38 & 38279.0 & 102.30 & 42.97 \\
\hline 2011 & 835.78 & 8.69 & 153911916 & 31.22 & 43.00 & 3.65 & 38288.0 & 101.50 & 40.21 \\
\hline 2012 & 856.34 & 6.78 & 155727053 & 31.99 & 40.10 & 3.91 & 38315.0 & 104.40 & 50.00 \\
\hline 2013 & 951.88 & 7.35 & 157571292 & 32.76 & 38.10 & 4.42 & 38357.0 & 108.60 & 49.00 \\
\hline 2014 & 1084.56 & 6.40 & 159405279 & 33.53 & 34.60 & 4.42 & 63702.0 & 108.40 & 46.00 \\
\hline 2015 & 1210.15 & 5.90 & 161200886 & 34.30 & 33.00 & 4.42 & 64692.0 & 109.20 & 36.13 \\
\hline 2016 & 1358.77 & 5.44 & 162951560 & 35.08 & 392.30 & 4.34 & 64821.0 & 112.10 & 33.94 \\
\hline 2017 & 1516.51 & 5.85 & 164669751 & 35.85 & 282.00 & 4.36 & 64627.0 & 111.09 & 30.05 \\
\hline 2018 & 1913.00 & 5.68 & 163650000 & - & - & 4.38 & 66269.0 & 114.23 & 37.00 \\
\hline
\end{tabular}




\section{Appendix: C}

Table 3. Political Variables

\begin{tabular}{|c|c|c|c|c|c|c|}
\hline Year & DEF & DGOV & IDT & GRANT & VOP & ELEC \\
\hline 1980 & 0.00 & 0 & 67.81 & 22.53 & 51.29 & o \\
\hline 1981 & 1.10 & 0 & 65.57 & 27.55 & 51.29 & 0 \\
\hline 1982 & 0.00 & 0 & 62.12 & 21.03 & 51.29 & 0 \\
\hline 1983 & 0.00 & 0 & 60.56 & 22.47 & 51.29 & 0 \\
\hline 1984 & 0.00 & 0 & 60.08 & 12.43 & 51.29 & 0 \\
\hline 1985 & 0.00 & 0 & 63.06 & 4.10 & 51.29 & o \\
\hline 1986 & 0.00 & 0 & 62.03 & 3.81 & 66.31 & 1 \\
\hline 1987 & 0.00 & 0 & 61.30 & 3.53 & 66.31 & o \\
\hline 1988 & -8.01 & 0 & 57.69 & 4.21 & 51.81 & 1 \\
\hline 1989 & -0.02 & 0 & 55.79 & 4.12 & 51.81 & 0 \\
\hline 1990 & -36.60 & 0 & 55.87 & 2.70 & 51.81 & 0 \\
\hline 1991 & -25.50 & 1 & 54.78 & 2.60 & 55.45 & 1 \\
\hline 1992 & -16.00 & 1 & 64.43 & 2.60 & 55.45 & 0 \\
\hline 1993 & -50.40 & 1 & 77.27 & 2.10 & 55.45 & 0 \\
\hline 1994 & -34.30 & 1 & 79.34 & 2.30 & 55.45 & 0 \\
\hline 1995 & -50.70 & 1 & 83.70 & 1.70 & 55.45 & 0 \\
\hline 1996 & -35.60 & 1 & 84.31 & 1.70 & 74.96 & 1 \\
\hline 1997 & -42.50 & 1 & 84.54 & 1.30 & 74.96 & 0 \\
\hline 1998 & -70.90 & 1 & 83.84 & 1.30 & 74.96 & o \\
\hline 1999 & -107.40 & 1 & 82.29 & 1.50 & 74.96 & 0 \\
\hline 2000 & -111.80 & 1 & 81.04 & 1.10 & 74.96 & 0 \\
\hline 2001 & -80.70 & 1 & 80.13 & 1.30 & 75.59 & 1 \\
\hline 2002 & -101.40 & 1 & 79.81 & 0.80 & 75.59 & 0 \\
\hline 2003 & -113.00 & 1 & 80.22 & 0.80 & 75.59 & 0 \\
\hline 2004 & -137.90 & 1 & 81.44 & 0.70 & 75.59 & 0 \\
\hline 2005 & -137.10 & 1 & 80.69 & 0.80 & 75.59 & 0 \\
\hline 2006 & -152.10 & 1 & 78.04 & 0.70 & 75.59 & 0 \\
\hline 2007 & -286.80 & 0 & 76.49 & 0.80 & 75.59 & 0 \\
\hline 2008 & -200.30 & 1 & 75.06 & 0.70 & 87.13 & 1 \\
\hline 2009 & -273.00 & 1 & 73.67 & 0.50 & 87.13 & o \\
\hline 2010 & -306.00 & 1 & 68.22 & 0.50 & 87.13 & o \\
\hline 2011 & -418.70 & 1 & 66.52 & 0.40 & 87.13 & 0 \\
\hline 2012 & -443.80 & 1 & 63.11 & 0.40 & 87.13 & 0 \\
\hline 2013 & -536.00 & 1 & 61.46 & 0.40 & 87.13 & 0 \\
\hline 2014 & -706.20 & 1 & 59.39 & 0.40 & 51.37 & 1 \\
\hline 2015 & -821.30 & 1 & 64.21 & 0.30 & 51.37 & 0 \\
\hline 2016 & -939.80 & 1 & 59.38 & 0.20 & 51.37 & o \\
\hline 2017 & -1075.84 & 1 & 70.14 & 0.20 & 51.37 & o \\
\hline 2018 & -1212.42 & 1 & 70.14 & 4.12 & 80.41 & 1 \\
\hline
\end{tabular}

\section{Appendix: D}

Table 4. Governance Indicators

\begin{tabular}{|c|c|c|c|c|}
\hline Year & GE & RQ & RL & CC \\
\hline 1996 & -0.69 & -0.93 & -0.93 & -0.93 \\
\hline 1997 & - & - & - & - \\
\hline 1998 & -0.44 & -0.81 & -0.89 & -0.72 \\
\hline 1999 & - & - & - & - \\
\hline 2000 & -0.58 & -0.84 & -0.91 & -1.11 \\
\hline 2001 & - & - & - & - \\
\hline 2002 & -0.69 & -0.98 & -0.90 & -1.36 \\
\hline 2003 & -0.73 & -0.92 & -1.05 & -1.44 \\
\hline 2004 & -0.82 & -1.13 & -1.02 & -1.50 \\
\hline 2005 & -0.91 & -1.07 & -0.98 & -1.39 \\
\hline 2006 & -0.82 & -1.00 & -0.90 & -1.43 \\
\hline 2007 & -0.70 & -0.95 & -0.83 & -1.06 \\
\hline 2008 & -0.73 & -0.92 & -0.75 & -1.03 \\
\hline 2009 & -0.79 & -0.86 & -0.79 & -1.07 \\
\hline 2010 & -0.74 & -0.85 & -0.80 & -1.06 \\
\hline 2011 & -0.76 & -0.81 & -0.73 & -1.09 \\
\hline 2012 & -0.80 & -0.95 & -0.93 & -0.85 \\
\hline 2013 & -0.79 & -0.91 & -0.87 & -0.89 \\
\hline 2014 & -0.77 & -0.94 & -0.78 & -0.89 \\
\hline 2015 & -0.72 & -0.90 & -0.75 & -0.81 \\
\hline 2016 & -0.68 & -0.80 & -0.66 & -0.86 \\
\hline 2017 & -0.74 & -0.81 & -0.67 & -0.83 \\
\hline 2018 & - & - & - & - \\
\hline
\end{tabular}




\section{Macrothink}

\section{Appendix: E}

Table 5. Descriptive statistics

\begin{tabular}{|c|c|c|c|c|c|}
\hline & N & Minimum & Maximum & Mean & S. D \\
\hline TGE & 39 & .93 & 2.82 & 1.7421 & .45170 \\
\hline ECAP & 39 & 73.92 & 26963.77 & 3169.5474 & 5430.69864 \\
\hline GU & 39 & $3507 . .06$ & 1122648.45 & 104420.9574 & 187077.39141 \\
\hline GS & 39 & 4250.38 & 2170183.20 & 298504.6458 & 401095.17029 \\
\hline GP & 39 & 7088.26 & 1317491.85 & 252799.0587 & 294386.78095 \\
\hline LAG_EXP & 39 & 201.00 & 49010.00 & 9142.3332 & 12731.82708 \\
\hline IDT & 39 & 54.78 & 84.54 & 70.1422 & 9.69772 \\
\hline INF & 39 & 1.94 & 18.49 & 7.2723 & 3.44889 \\
\hline GLOB & 39 & 16.68 & 392.30 & 44.9561 & 71.56620 \\
\hline SCH & 39 & 36952.0 & 66269.0 & 41442.103 & 9104.1188 \\
\hline GRANTS & 39 & .20 & 27.55 & 4.1205 & 6.98066 \\
\hline POP & 39 & 81470860 & 164669751 & 126833491.49 & 26141986.427 \\
\hline STR_P & 39 & 30.05 & 117.85 & 65.0802 & 27.69679 \\
\hline CC & 19 & -1.50 & -.72 & -1.0695 & .24339 \\
\hline
\end{tabular}

\section{Copyright Disclaimer}

Copyright for this article is retained by the author(s), with first publication rights granted to the journal.

This is an open-access article distributed under the terms and conditions of the Creative Commons Attribution license (http://creativecommons.org/licenses/by/4.0/). 